To the Editors:

\title{
A case of paroxysmal cold haemoglobinuria following chickenpox
}

Paroxysmal Cold Haemoglobinuria (PCH) is a rare type of cold haemolytic anaemia (HA), characterized by intravascular haemolysis due to an IgG antibody named after Donath Landsteiner. PCH is usually associated with viral infections, but association with varicella zoster infection (VZI) is rare in adults. We present the second such reported adult case, which is the first in Sri Lanka [1].

A 17 year old, previously healthy girl, developed vomiting, fever and faintishness, and two bouts of dark red urine suggestive of haemoglobinuria. She had features of recent VZI, with healing vesicles. She was pale, jaundiced, and had features of heart failure. She had marginal hepatomegaly on abdominal examination.

Investigations showed a very low $\mathrm{Hb}$ of $2.3 \mathrm{~g} / \mathrm{dl}$, platelet count of $3.89 \times 10^{9} / \mathrm{l}$, and white cell count of $11.8 \times$ $10 \%$ l (neutrophils $85 \%$ ). Blood picture showed cold type HA, but failed to show any erythro-phagocytic neutrophils. She had a high ESR $(125 \mathrm{~mm} / \mathrm{hr})$ and high ferritin (312 nmol/l [ref. 0.27 - $0.337 \mathrm{nmol} / \mathrm{l}]$ ) levels. Serum iron was $178 \mu \mathrm{mol} / 1$, TIBC was $240 \mu \mathrm{mol} / 1$ and transferrin saturation was $74 \%$. Liver function tests showed increased serum bilirubin levels (total $25.6 \mathrm{mmol} / \mathrm{l}$, direct $5.2 \mathrm{mmol} / \mathrm{l}$ ) with normal enzyme levels. She had normal abdominal ultra sonography. Renal function tests, urine analysis and culture were normal. Direct Coomb's test was weakly positive with poly-specific anti-human globulin, and the indirect test was negative. Cold agglutinins were negative after screening at $4{ }^{\circ} \mathrm{C}$ against adult (I), cord (i) and autologous erythrocytes. Donath-Landsteiner antibody was positive, confirming the diagnosis. However, anti-P antigen specificity was not tested. Mycoplasma antibodies, HIV screening, VDRL, hepatitis B antibodies, Rheumatoid Factor and Anti Nuclear Antibodies were negative. G6PD assay, Epstein-Barr serology and osmotic fragility were not performed.

She was treated with high dose prednisolone (1mg / $\mathrm{kg}$ / day), with six packs of leucodepleted $\mathrm{P}$ antigen positive red cell concentrates (LDRCC) (cross matched at $37^{\circ} \mathrm{C}$ ), folate supplementation and was nursed warm. After one week, she was discharged with a $\mathrm{Hb}$ of $9 \mathrm{~g} / \mathrm{dl}$, with no further evidence of haemolysis. Three months later, she was asymptomatic.
$\mathrm{PCH}$ was first described as a chronic relapsing haemolytic anemia, but this picture is rare now. The acute non-relapsing form of $\mathrm{PCH}$ has been documented to occur in adults as isolated cases, associated with illnesses such as infectious mononucleosis, Mycoplasma pneumoniae and Klebsiella pneumoniae infections, nonHodgkin lymphoma [1], myelo-dysplastic syndromes [2], myeloproliferative syndromes [3], and small cell carcinoma [4].

The management of the condition was based on isolated case reports. Steroid therapy has generally not been found to be beneficial, but may be useful in atypical presentations (i.e. Evan syndrome) [1,4]. Rituximab and azathioprine have been shown to be beneficial in refractory cases $[5,6]$.

\section{References}

1. Papalia MA, Schwarer AP. Paroxysmal cold hemoglobinuria in an adult with chicken pox. British Journal of Haematology 2000; 109: 328-9.

2. Stefanizzi C, Breccia M, Santopietro M, et al. Unusual association of paroxysmal cold haemoglobinuria as the first sign of disease in myelodysplastic patient. International Journal of Hematology 2009; 89: 720-1.

3. Breccia M, D'Elia GM, Girelli G, et al. Paroxysmal cold hemoglobinuria as a tardive complication of idiopathic myelofibrosis. European Journal of Haematology 2004; 73: 304-6.

4. Lippman SM, Winn L, Grumet FC, Levitt LJ. Evans' syndrome as a presenting manifestation of atypical paroxysmal cold hemoglobinuria. American Journal of Medicine 1987; 82: 1065-72.

5. Koppel A, Lim S, Osby M, Garratty G, Goldfinger D. Rituximab as successful therapy in a patient with refractory paroxysmal cold hemoglobinuria. Transfusion 2007; 47: 1902-4.

6. Nakamura H, Watanabe T, Hayashida T, Ichimaru M. Donath-Landsteiner antibody of the IgM class with anti-I specificity and possible efficacy of azathioprine therapy in paroxysmal cold hemoglobinuria: a case report. Rinsho Ketsueki 1990; 31: 1548-52.

\section{R M Weerakkody ${ }^{1}$, N N Ranasinghe ${ }^{2}$, F G Sivagnanam ${ }^{3}$}

Departments of ${ }^{1}$ Medicine and ${ }^{2}$ Haematology, Colombo South Teaching Hospital, Sri Lanka.

Correspondence: RMW, e-mail <rangamw2003@yahoo.com>. Received 16 September 2009 and revised version accepted 20 February 2009. Competing interests: none declared. 